\title{
ПРИКЛАДНЫЕ АСПЕКТЫ ИССЛЕДОВАНИЯ ОНОМАСТИЧЕСКИХ РЕАЛИЙ (НА МАТЕРИАЛЕ АМЕРИКАНСКИХ АНТРОПОНИМОВ И ТОПОНИМОВ АЭРОКОСМИЧЕСКОЙ ТЕМАТИКИ)
}

\section{APPLIED ASPECTS OF ONOMASTIC REALIA STUDY (BASED ON THE MATERIAL OF AEROSPACE ANTHROPONYMS AND TOPONYMS)}

\section{Korotaeva \\ D. Kapustina}

Summary: The article is devoted to the analysis of practical implication of American onomastic realia investigation. The authors selected aerospace anthroponyms and toponyms as a base of study and analyzed the problems of teaching students to work with this kind of vocabulary during the course of English language at technical university of aerospace field of training. In addition, the authors came to the conclusion that onomastic realia can be regarded as an important aspect of English language course, helping students to get deeper understanding of the historical development of their professional field. The significance of the analysis of onomastic realia is justified by their ability to clarify specific features of the national worldview. The onomastic lexical units are characterized by temporal orientation and reflect cultural and historical development of the country and its native speakers.

Keywords: language and culture, onomastic realia, onym, anthroponym, toponym, background knowledge.
$\mathrm{O}$ номастические реалии обладают яркой национальной окраской, являются носителями определённого национального и временного колорита, поэтому они были и остаются предметом исследования в области линвострановедения и лингвокультурологии. Распознавание данного вида реалий в тексте чаще всего не вызывает сложностей, однако выбор способа передачи их на русский язык не всегда очевиден. Кроме того, за каждой ономастической лексической единицей стоит значительный объём фоновой информации, за которой достаточно часто приходится обращаться к энциклопедическим источникам.

С начала с 50-х годов XX века проблема функционирования ономастических реалий привлекала внимание таких исследователей как Л.С. Бархударов, В.В. Виноградов, С. Влахов, С. Флорин, Г.Д. Томахин и др. Современные лингвисты отмечают специфику колорита этих языковых явлений как особых своеобразных национально-окра-
Коротаева Ирина Эдуардовна

к.филол.н., доцент, Московский авиационный институт (национальный исследовательский университет) irinakorotaeva@mail.ru

Капустина Дарья Михайловна

к.ф.н., доцент, Московский авиационный институт (национальный исследовательский университет) popovski2003@mail.ru

Аннотация: Данная работа посвящена анализу практического значения исследований ономастических реалий и выполнена на материале американских топонимов и антропонимов аэрокосмической тематики. Актуальность исследования связана с особым значением данного пласта лексики в составе любого языка. Необходимость уделять ономастической лексике пристальное внимание возникает во всех случаях работы с языком (переводчики, преподаватели иностранного языка). В данном исследовании рассматриваются проблемы работы с ономастической лексикой аэрокосмической тематики на занятиях со студентами соответствующих направлений подготовки. Отмечается роль подобной лексики как в формировании общего представления студентов о культуре и истории страны изучаемого языка, так и в формировании более глубокого понимания исторического развития сферы их профессионального интереса - авиации и космонавтики. Ономастические реалии, отражающие культурно-историческое развитие народа-носителя языка, и являющиеся временными ориентирами, очень важны для правильного понимания иноязычного текста, а также для более глубокого погружения в историю и культуру иностранного языка.

Ключевые слова: язык и культура, ономастические реалии, оним, антропоним, топоним, фоновые знания.

шенных языковых субстанций [2. С.66].

Г.Д. Томахин относит к ономастическим реалиям антропонимы, топонимы, названия произведений литературы и искусства, названия исторических фактов и событий в жизни страны, названия общественных учреждений и т.д. Под антропонимами понимаются имена исторических личностей, общественных деятелей, учёных, писателей, персонажей художественной литературы и т.д. Топонимы (географические названия) интересны с точки зрения наличия в них культурно-исторических ассоциаций [12.С.8].

Анализируя антропонимы, топонимы и эргонимы (названия предприятий), исследователи отмечают, что особенность ономастических реалий заключается в их существенной зависимости от социокультурных обстоятельств, например от социальных отношений, быта, политической обстановки [7. С.140]. 
Интерес представляют исследования, посвящённые типологической характеристике и особенностям ономастических реалий-неологизмов, под которыми исследователи понимают имена собственные, передающие присущие только данному народу культурные особенности, обладающие новизной как в плане содержания, так иногда и в плане выражения. Такие реалии присутствуют в определённую эпоху и отсутствуют в предыдущие периоды времени, не зафиксированы в толковых словарях определённого языка, однако употребляются в средствах массовой информации $[3,4]$.

Актуальным представляется анализ ономастических реалий, отражающих национально-культурный колорит страны, в художественных произведениях. Проводится исследование их с точки зрения этимологических составляющих, выявляются основные закономерности применения переводческого приёма, используемого для их передачи. Для достижения данных целей авторы используют различные методы, например, сопоставительный метод для нахождения сходств и различий (анализ лексем из разных языков, отражающих национально-культурный код разных стран); описательный метод (инвентаризация слов-реалий); сравнительный метод (выявление сходств и различий при переводе реалий на разные языки) [11].

Использование ономастических реалий в тексте рассматривается авторами как одно из средств, способствующих усилению образности и выразительности как конкретного высказывания, так и текста в целом [15].

Все реалии являются частью фоновых знаний и представляют собой значительный интерес при исследовании взаимодействия языка и культуры [14. С.178]. Рассматривая ономастические реалии в лингвокультурологическом аспекте изучения иностранного языка, учёные отмечают, что ономастика отличается комплексностью предмета исследования, и, при доминирующем лингвистическом, включает и другие аспекты. Онимы относятся к фоновой лексике и содержат исторически ценную информацию, в расшифровке которой принимают участие как лингвисты, так и представители различных научных направлений, например, историки, культурологи, археологи, географы. Всё это свидетельствует о необходимости изучения онимов как важнейших языковых источников [10. С.138].

Отмечается, что для осуществления эквивалентного перевода текста, содержащего ономастические реалии, следует анализировать смысловые и культурно-прагматические аспекты всего текста, задумываться над выбором наиболее оптимальных стратегий и приёмов перевода для каждого конкретного случая [5. С.90].

Прикладной характер исследования ономастиче- ских реалий обусловлен необходимостью организации работы как переводчиков, так и преподавателей иностранного языка на всех этапах обучения таким образом, чтобы данные лексические единицы всегда оставались в поле пристального внимания. Ономастические реалии представляют собой «живую» и подвижную систему [6]. Темпоральный характер ономастических реалий заставляет при работе с иноязычным текстом как обращаться к истории, так и быть в курсе текущих событий, хорошо ориентируясь в разнообразных именах и названиях.

Всё вышесказанное свидетельствует о том, что для осуществления качественного перевода следует решать следующие задачи:

- отбор ономастических реалий при работе с текстом;

- правильное определение временного периода функционирования конкретной реалии;

- поиск информации, касающейся конкретной реалии;

- комментирование реалий;

- анализ и выбор наиболее подходящих способов передачи реалии.

Несмотря на кажущуюся простоту поставленных задач, иногда бывает сложно найти информацию о том или ином недостаточно известном человеке или событии, указанном в тексте. Иногда приходится анализировать найденную в Интернете информацию на предмет её достоверности и самостоятельно переводить ономастическую реалию, выбирая между несколькими возможными способами передачи реалии.

Актуальным представляется обучение работе с ономастическими реалиями в иноязычных текстах на занятиях по иностранному языку в вузе. Обобщая опыт преподавания иностранного языка в техническом вузе, отметим, что ономастическая лексика должна присутствовать в учебных текстах, давая студентам возможность глубже познакомиться как с историей, так и с современными достижениями науки и техники, касающимися области их профессиональных интересов. Так, например, студенты должны знать и уметь излагать на иностранном языке информацию, касающуюся отечественных выдающихся личностей, поэтому в программу обучения иностранному языку должны входить тексты, посвящённые отечественной науке и технике. Иногда студент-первокурсник не очень хорошо ориентируется в подобной информации, поэтому курс иностранного языка должен способствовать ликвидации таких «пробелов». На занятиях по английскому языку следует работать с научно-популярными текстами, содержащими ономастическую лексику англоговорящих стран, и предоставляющими студентам фоновую информацию, касающуюся стран изучаемого языка. В данном случае можно говорить о междисциплинарном аспекте препо- 
давания иностранного языка, позволяющем данной дисциплине участвовать в погружении студента в выбранную специальность.

При работе с ономастическими реалиями в определённой области науки и техники целесообразно провести их отбор с последующей классификацией [6. С.343]. Сами реалии и фоновые знания, стоящие за ними, представляют профессиональный интерес для студентов, поэтому на занятиях по английскому языку следует знакомить с ними обучающихся с учётом их направлений подготовки. Особое внимание следует уделять комментированию реалий.

Используя лингвостарановедческие словари [1], [8], [13], приведём примеры американских ономастических реалий аэрокосмической тематики, сопроводив их линвокультурологическим комментарием. Антропонимы:

1. Wright Brothers - братья Райm. Пионеры авиации, с которыми связано начало «эры авиации», американские авиаконструкторы Wilbur Wright (Вилбур/или Уилбур, Уилбер Райт) и Orville Wright (Орвил Райт).

2. Langley, Samuel Pierpont - Самюэль Пирпонт Лэнгли. Изобретатель, пионер воздухоплавания. Провёл серию экспериментов по созданию летательных аппаратов тяжелее воздуха.

3. Chanute, Octave - Октав Шанют. Один из пионеров авиации, инженер. Помогал братьям Райт в их работе, опубликовал результаты их экспериментов. Собрал данные об экспериментах в области авиации во всём мире.

4. Lindbergh, Charles Augustus - Чарльз Огастес Линдберг. Авиатор, общественный деятель. В 1927 г. совершил трансконтинентальный перелёт с одной промежуточной посадкой из СанДиего (штат Калифорния) на Лонг-Айленд и установил рекорд скорости. Прозвище «The Lone Eagle»/«Одинокий орел».

5. Goddard, Robert Hutchings - Роберт Хатчингс Годдард. Пионер ракетостроения, физик. В 1914 г. первым сконструировал двухступенчатую ракету. В 1926 г. впервые в мире произвёл пуск жидкостной ракеты. Работал над созданием гироскопической системы управления полётом ракеты. Имя Годдарда присвоено кратеру на Луне (Goddard).

6. Armstrong, Neil.A. and Aldrin, Jr., Edwin E. - Нил Армстронг и Эдвин Юджин Олдрин. Первые астронавты, ступившие на поверхность Луны (июль 1969г.).

7. Van Allen, James Alfred - Джеймс Алфред Ван Аллен. Один из пионеров постановки геофизических и астрофизических исследований на высотных ракетах, искусственных спутниках и космических кораблях. Физик, астрофизик.

Имя Джеймса Алфреда Ван Аллена было использо- вано для образования ономастической терминологии из области астрофизики и планетологии: «Пояса Ван Аллена» (Van Allen belts) или «радиационный пояс Ван Аллена» (Van Allen radiation belt); «Зонды Ван Аллена» (Van Allen Probes).

Актуальными представляются антропонимы, относящиеся к истории советско-американских отношений в области космических исследований. Участниками двухдневной стыковки американского космического корабля «Apollo» («Аполлон») и советского космического корабля «Союз-19» (Apollo-Soyuz test project - космический полёт «Союз-Аполлон») были:

- с американской стороны: Stafford, Thomas P.; Slayton, Donald K.; Brand, Vance D. - астронавты Томас Стаффорд, Доналд Слейтон, Вэнс Бранд.

- с советской стороны: космонавты Леонов Алексей Архипович и Кубасов Валерий Николаевич (Leonov Alexei Arkhipovich and Kubasov Valery Nikolaevich) (июль 1975 г.). Кубасов В.Н. в 1958 году окончил Московский авиационный институт (МАИ), самолётостроительный факультет.

Достаточно интересным с точки зрения наличия культурно-исторических ассоциаций примером топонима является Kitti Hawk (Китти-Хок) - название посёлка, где братья Райт совершили свои первые полёты (1903г.). Далее с этим топонимом стали связывать следующие названия: Kitty Hawk, U.S.S. (ударный авианосец BMC); Curtis P-40 Kittyhawk, P-40 Warhawk (Tomahawk) (Кёртисc P-40 Киттихок - американский истребитель времён Второй мировой войны, разработанный корпорацией КёртиссРайт (Curtiss-Wright Corporation)). В.В. Ощепкова отмечает, что топоним может создавать в тексте ориентир времени [9]. В данном случае с названием Kitty Hawk будет связано не только географическое название, но и начало эры авиации. Ассоциации с данной реалией повлияли и на появление новых названий, например, ударный авианосец BMC был назван USS Kitty Hawk. Г.Д. Томахин относит лексическую единицу Kitti Hawk к группе «мемориальных топонимов» - названий, мотивированных именами выдающихся людей [12]. Название холма КиллДевил-Хилл (Kill Devil Hill), который был выбран братьями Райт для своих экспериментальных полётов благодаря постоянным устойчивым ветрам и уединённости, также может служить примером мемориального топонима.

В заключение отметим, что пристальное внимание теоретиков и практиков к ономастической лексике не ослабевает, так как постоянно появляются всё новые и новые ономастические реалии, отражающие культурноисторическое развитие народа-носителя языка. Являясь временными ориентирами, подобные лексические единицы очень важны для правильного понимания иноязычного текста, а также для более глубокого погружения в историю и культуру иностранного языка. 


\section{ЛИТЕРАТУРА}

1. Американа: Англо-русский лингвострановедческий словарь/Под ред. Г.В. Чернова. - М.: Полиграмма, 1996. - 1187 с.

2. Арутюнян В.С. Ономатические реалии в национальной фразеологии (на материале английского и немецкого языков)//ВМгоу. Серия: 0бщественно-политические и гуманитарные науки. 2011. № 3. С. 65-68.

3. Бугрышева Е.С. Типологическая характеристика ономастических реалий-неоогизмов (на материале французких, английских и русских СМИ)// Вестник МГОУ. 2017. №4.

4. Бугрышева Е.С. Особенности английских и французских ономастических реалий-неолошизмов (на материале англоязычного и франкоязычного телевизионных дискурсов)// Вестник МГОУ. 2015. №3.

5. Гудий К.А. Общие рекомендации переводчику по передаче ономастических реалий//Иностранные языки: лингвистические и методические аспекты. 2016. № 36. С. 87-91.

6. Коротаева И.Э. Классификация ономастических реалий авиационной и космической тематики//Мир науки, культуры, 0бразования. 2016. № 6 (61). С. $343-346$.

7. Крылова К.М. Особенности перевода ономастических реалий в медиадискурсе / В книге: Язык текущего момента. Материалы IV международной студенческой научно-практической конференции. Москва, 2021. С. 140-142.

8. Ощепкова В.В., Шустилова И.И. Краткий англо-русский лингвострановедческий словарь: Великобритания, США, Канада, Австралия, Новая Зелландия. М.: Флинта: Наука, 2001. - 176с.

9. Ощепкова В.В. Язык и культура Великобритании, США, Канады, Австралии, Новой Зеландии. - М.-СПб.: Изд-во Глосса/ Каро, 2006. - 336 с.

10. Пригодич Е.А. Ономатические реалии в лингвокультурологическом аспекте изучения иностранного языка/В сборнике: Языковая личность и эффективная коммуникация в современном поликультурном мире. материалы V Международной научно-практической конференции, посвященной 20-летию основания кафедры теории и практики перевода факультета социокультурных коммуникаций БГУ. 2019. С. 138-142.

11. Старцева С.М. Ономатические реалии в англоязычных художественных произведениях Роберта Ван Гулика и способы их передачи на китайский и русский языки//Вестник МГОУ.2018. №2.

12. Томахин Г.Д. Реалии-американизмы. - М.: Высшая школа, 1988. - 240 с.

13. Томахин Г.Д. США. Лингвострановедческий словарь. - М.: Рус.яз., 1999. - 576 с.

14. Халилуллина 3., Ибрагимова К.Г. К проблеме перевода ономастических реалий/В сборнике: Секция «Актуальные проблемы социально-гуманитарного знания». Сборник докладов в рамках Московской молодёжной научно-практической конференции. Ответственный редактор: Каллиопин А. К., 2015. C. 178-184.

15. Mamatkulova B.R. The linguo-cultural acpects of onomastic lexeme. https://problemspedagogy.ru/images/PDF/2018/39/the-linguo-cultural.pdf

○ Коротаева Ирина Эдуардовна (irinakorotaeva@mail.ru), Капустина Дарья Михайловна (popovski2003@mail.ru).

Журнал «Современная наука: актуальные проблемы теории и практики» 